\title{
Carotid or jugular amino acid infusions and food intake in the cockerel
}

\author{
BY G. TOBIN* AND K. N. BOORMAN \\ Department of Applied Biochemistry and Nutrition, University of Nottingham School \\ of Agriculture, Sutton Bonington, Loughborough, Leics. LE $125 R$ \\ (Received I 3 April I978 - Accepted 20 June 1978)
}

\begin{abstract}
1. Infusions of histidine into the carotid arteries of cockerels receiving a histidine-limiting, imbalanced diet caused an increase in food intake, whereas similar infusions into the jugular veins did not.

2. Infusions of lysine into the carotid arteries or jugular veins of young cockerels receiving a balanced, low-protein diet caused decreases in food intake. There was evidence of a more marked effect of carotid infusion.

3. The mechanisms of food intake regulation by amino acids in mammals are applicable to birds and excesses of single amino acids do seem to affect food intake directly.
\end{abstract}

Diets containing excesses of essential amino acids either singly or combined in groups cause decreases in voluntary food intake. This effect can be rapid and is preceded by changes in the blood amino acid pattern. Several authors have proposed that the deranged blood pattern initiates the response in food intake (see Harper et al. 1970) and this is consistent with the more general aminostatic hypothesis of food intake control proposed by Mellinkoff ( 1957 ).

The sites sensitive to these deranged patterns are being identified in laboratory mammals, especially with respect to amino acid imbalanced and deficient diets (Leung \& Rogers, I 97I; Rogers \& Leung, 1973). However, the relationship between excess of a single amino acid and food intake is not as clearly defined.

As poultry are sensitive to changes in amino acid pattern of the diet and knowledge of their systems of food intake control is limited, experiments were undertaken using the approach of Leung \& Rogers ( 1969 ) to ascertain the extent to which the findings with rats could be applied to poultry and to attempt to resolve the question of whether excesses of single amino acids directly affect food intake.

\section{EXPERIMENTAL}

The experiments involved the infusion of an amino acid either via the carotid artery or jugular vein into cockerels receiving diets that were balanced or imbalanced in respect of amino acid composition, and the observation of the effects on food intake. The excess lysine and histidine-limiting conditions used in the present studies have been shown previously (Tobin, 1974) to produce responses typical of diets containing excesses of essential amino acids either singly or combined in groups.

\section{Surgical and infusion procedures}

Details of procedures are described by Tobin (1974). Young cockerels of a laying strain (Warren SSL; Warren-Studler Breeding Farm Ltd, Peterborough) weighing approximately I $\mathrm{kg}$ were anaesthetized with intravenous pentobarbitone sodium (Nembutal; Abbott Laboratories Ltd, Queensborough, Kent).

For cannulation of the carotid artery the arteries were located by dissection of the neck from the ventral aspect, and by further careful dissection one of the arteries (usually the

\footnotetext{
* Present address: Department of Physiology, The Liniversity, Leeds LS2 9JT.
} 


$\begin{array}{lr}\text { Table I. Composition }(\mathrm{g} / \mathrm{kg}) \text { of low-protein diet } \\ \quad \text { Ingredient } \\ \text { Ground wheat } & 500 \\ \text { White-fish meal } & 60 \\ \text { Dextrose monohydrate } & 240 \\ \text { Maize oil } & 50 \\ \text { Kaolin } & 50 \\ \text { Cellulose powder } & 50 \\ \text { Vitamin-mineral supplement* } & 50 \\ \quad \text { Determined essential amino acids } & \\ \text { Arginine } & 5 \cdot 4 \\ \text { Lysine } & 5 \cdot 1 \\ \text { Histidine } & 2 \cdot 4 \\ \text { Methionine+cystine } & 5 \cdot 2 \\ \text { Tryptophan } & 0 \cdot 9 \\ \text { Glycine } & 8 \cdot 2 \\ \text { Phenylalanine + tyrosine } & 7 \cdot 8 \\ \text { Leucine } & 8 \cdot 0 \\ \text { Isoleucine } & 4 \cdot 2 \\ \text { Threonine } & 3 \cdot 5 \\ \text { Valine } & 4 \cdot 3 \\ & \end{array}$

left) was removed from the common connective tissue sheath in which they are encased. This artery was then ligated close to the thorax. A polypropylene cannula (Argyle Medicut 20G; Sherwood Medical Industries Ltd, Crawley, Sussex) was introduced in a cranial direction and secured with ligatures. The free end of the cannula was then connected to a length of tubing which had been introduced under the skin from the ventrolateral aspect of the left wing. This tubing was of a size suitable for connexion to the infusion system. After removal of air bubbles the tubing and cannula were filled with heparinized saline ( $9 \mathrm{~g}$ sodium chloride/l) and secured by suturing the tubing to the deep pectoral muscle. The incision in the neck was closed with silk sutures, wounds were treated with antibiotic spray (Dispray; Avlex Ltd, Wigan, Lancs.) and covered with plastic skin (Nobecutane; BDH Pharmaceuticals, London). Thus the bird could be infused via a secure tube which protruded from near the wing and was connected sub-epidermally to a carotid artery.

Cannulation of the jugular vein was essentially similar. These vessels lie independently in the subcutaneous tissue. The cannula was introduced in a caudal direction and was connected in the same way to a length of tubing introduced sub-epidermally through a lateral incision in the neck. Both skin incisions made during the cannulation of the jugular vein were sutured and treated as described previously. Different birds were used for each type of cannulation. After surgery the birds were allowed to recover in a warm room and could be used for infusion experiments after $24 \mathrm{~h}$.

To allow the birds free access to food and water within a cage while being infused, it was necessary to support the infusion tubes and allow movement. This was effected by connecting the tube from the bird, allowing ample tubing for movement, to the outlet of a leak-proof swivel which was fixed to the roof of the cage. The inlet of the swivel was connected to a peristaltic pump (MHRE 22 Delta; Watson-Marlow Ltd, Falmouth, Cornwall). The cannulated birds were thus able to move, feed and drink freely.

\section{Diets and amino acid infusions}

The low-protein balanced diet (Table I) was designed to provide roo g crude protein (nitrogen $\times 6 \cdot 25) / \mathrm{kg}$ and essential amino acids in approximately optimal proportions for a 
Table 2. Imbalancing supplement of amino acids lacking histidine $\left(\mathrm{g} / \mathrm{kg}\right.$ diet $\left.{ }^{*}\right)$

$\begin{array}{lr}\text { L-arginine† } & \text { I I I I } \\ \text { L-lysine } & \text { I I } 3 \\ \text { DL-methionine } & 8 \cdot 4 \\ \text { L-tryptophan } & 2 \cdot 3 \\ \text { glycine } & 12 \cdot \mathrm{I} \\ \text { L-phenylalanine } & 7 \cdot 5 \\ \text { L-tyrosine } & 7 \cdot 5 \\ \text { L-leucine } & \text { I } 4 \cdot \mathrm{I} \\ \text { DL-isoleucine } & 8 \cdot \mathrm{I} \\ \text { DL-threonine } & 8 \cdot \mathrm{I} \\ \text { L-valine } & 9 \cdot 5\end{array}$

* Substituted for equal parts of a mixture of kaolin and cellulose in low-protein diet (see Table I).

+ Added as hydrochlorides.

diet containing sufficient protein to allow normal growth. Other nutrients including minerals and vitamins were included in sufficient quantities. The histidine-limiting imbalanced diet was produced by substituting a mixture of essential amino acids lacking histidine (Table 2), at $100 \mathrm{~g} / \mathrm{kg}$, for equal parts of kaolin and cellulose in the low-protein diet. The amino acids in the mixture were in the same proportion as that between the requirements for these amino acids.

The effects on food intake of the ingestion of an excess of a single amino acid were studied by the infusion of $100 \mathrm{~g} \mathrm{~L}$-lysine hydrochloride/ $\mathrm{l}$ at a rate of $1 \mathrm{ml} / \mathrm{h}$. In order to attempt to correct the effects on food intake of the histidine-limiting imbalanced diet, infusions containing 10 or $20 \mathrm{~g} \mathrm{~L}$-histidine $/ \mathrm{l}$ were infused at $1 \mathrm{ml} / \mathrm{h}$. The amino acids were infused in Krebs-Ringer solution which included $0.1 \mathrm{M}$-phosphate buffer $(\mathrm{pH} 7 \cdot 4)$.

\section{Expt $\mathrm{I}$}

For 2 weeks before surgery the birds were fed on the low-protein diet, the composition of which is given in Table $I$.

After introducing the cannulas the birds were allowed to recover and two birds with carotid cannulas and two with jugular cannulas were caged individually and infused continuously with Krebs-Ringer solution at $\mathrm{I} \mathrm{ml} / \mathrm{h}$. Room temperature was maintained at $\mathrm{I} 5^{\circ}$ and lighting was continuous. Approximately $24 \mathrm{~h}$ after completion of surgery, by which time food intake was similar to unoperated birds of the same type and age, the birds were offered the histidine-limiting imbalanced diet. Soon thereafter each bird was infused with Krebs-Ringer solution with or without 10 or $20 \mathrm{~g} \mathrm{~L}$-histidine/1. After $\mathrm{I} 2 \mathrm{~h}$ the infusions were changed and after another $12 \mathrm{~h}$ changed again such that each bird received each of the three infusions once. In an attempt to minimize any possible 'time of day' effects on food intake (despite the continuous lighting regimen) each of the infusates was administered to at least one bird during each of the $12 \mathrm{~h}$ periods. Two birds, one representing each type of cannulation, were considered sufficiently normal to be used for a further three $\mathrm{I} 2 \mathrm{~h}$ periods of infusion and the experiment was repeated with these two birds. Food intake was measured every $6 \mathrm{~h}$ during each period of infusion.

\section{Expt 2}

The design of the experiment and the experimental conditions were essentially similar to those used in Expt $\mathrm{r}$. The diet offered was the low-protein balanced diet and the two infusions were Krebs-Ringer solution with or without lysine. The treatments were allocated in a Latin square arrangement. An experiment comprising two $6 \mathrm{~h}$ infusion periods for each 
Table 3. Effects of control (Krebs-Ringer solution) or histidine infusions via the carotid artery or jugular vein on food intake $(\mathrm{g} / 6 \mathrm{~h})$ in birds receiving a histidine-limiting imbalanced diet

(Values are means of a minimum of three replicates)

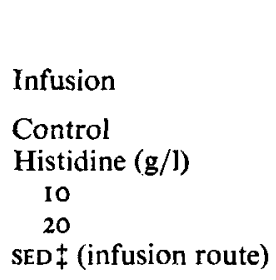

\begin{tabular}{|c|c|c|}
\hline \multicolumn{2}{|c|}{ Route } & \multirow{2}{*}{$\begin{array}{c}\text { SED } \dagger \\
\text { (type of infusion) }\end{array}$} \\
\hline Carotid & Jugular & \\
\hline $8 \cdot I$ & $12 \cdot 0$ & \\
\hline $\begin{array}{l}2 \mathrm{I} \cdot \mathrm{O}^{*} \\
22 \cdot 7^{* *}\end{array}$ & $\begin{array}{l}14 \cdot 7 \\
12 \cdot 8\end{array}$ & $3 \cdot 60$ \\
\hline & & \\
\hline
\end{tabular}

Significantly different from control infusion by same route: $* P<0.05, * * P<0.01$.

+ Standard error appropriate to difference between means of types of infusion (control $v$. 10 or $20 \mathrm{~g}$ histidine/l).

\$ Standard error appropriate to difference between means of routes of infusion (carotid $v$. jugular).

Table 4. Effects of control (Krebs-Ringer solution) or lysine infusion via the carotid artery or jugular vein on food intake $(\mathrm{g} / 6 \mathrm{~h})$ in birds receiving a balanced low-protein diet

(Values are means of a minimum of three replicates)

\begin{tabular}{|c|c|c|c|}
\hline \multirow[b]{2}{*}{ Infusion } & \multicolumn{2}{|c|}{ Route } & \multirow{2}{*}{$\begin{array}{c}\text { SED }{ }^{\dagger} \\
\text { (type of infusion) }\end{array}$} \\
\hline & Carotid & Jugular & \\
\hline $\begin{array}{l}\text { Control } \\
\text { Lysine } \\
\text { SED } \ddagger \text { (infusion route) }\end{array}$ & $\begin{array}{l}20 \cdot 2 \\
5 \cdot 8^{* *}\end{array}$ & $\begin{array}{l}24 \cdot 4 \\
13 \cdot 3^{* *}\end{array}$ & $2 \cdot 59$ \\
\hline
\end{tabular}

Significantly different from control infusion by the same route: ${ }^{* *} P<0.01$.

$\dagger$ Standard error appropriate to difference between means of types of infusion (control $v$. lysine).

$\$$ Standard error appropriate to difference between means of routes of infusion (carotid $\because$. jugular).

bird was repeated using $24 \mathrm{~h}$ infusion periods. Food intake was measured at $6 \mathrm{~h}$ intervals. The results from the four periods were pooled. One bird cannulated in the jugular vein was considered abnormally quiescent during the second $24 \mathrm{~h}$ period and food intake for this bird for both $24 \mathrm{~h}$ periods was omitted from analysis.

\section{Statistical analysis}

An analysis of variance for a split-plot design was carried out on the food intake values. Statistical differences were established by Dunnett's (1955) procedure for a two-sided comparison.

\section{RESULTS}

\section{Expt I}

When Krebs-Ringer solution alone was infused into birds receiving the imbalanced diet there was no significant effect of the route of infusion (Table 3) although there was an indication that food intake was less when the infusion was via the carotid. Inclusion of histidine in the infusion did not cause an increase in food intake in birds infused via the jugular vein, but there were significant increases in food intake when the infusion was via the carotid artery. There was no significant difference between infusions in the effects of the histidine concentrations. 


\section{Expt 2}

With the Krebs-Ringer infusion there was again an indication that carotid infusion may have caused some depression in food intake compared with jugular infusion (Table 4). Lysine infusion caused marked, highly significant decreases in food intake, irrespective of the route of infusion. Mean food intake in birds receiving lysine via the carotid artery was less than half that of birds similarly infused via the jugular vein. This difference was not conventionally statistically significant $(P=0.2)$, but we believe this reflects the variability in values collected by these difficult methods and the consequent small numbers of experimental animals that can be used, rather than true equivalence of the effects of the different routes of infusion.

\section{DISCUSSION}

The results (Expt I) show that the decreased food intake caused by imbalance arising from incomplete mixtures of amino acids can be corrected by infusion of the limiting amino acid via the carotid artery but that no such amelioration results from infusion via the jugular vein. These results confirm the findings of Leung \& Rogers (1969), who showed this effect in the rat receiving threonine- or isoleucine-limiting imbalanced diets. The present results indicate the general nature of the phenomenon both in terms of species and amino acids.

The more marked effect of infusions into the carotid artery than into the jugular vein has been interpreted to mean that there is an area in the brain sensitive to the pattern of amino acids in blood passing to the brain and that this area detects the deranged pattern caused by imbalance and is concerned in the initiation of the homeostatic response, the decrease in food intake (Leung \& Rogers, 1969). Infusion of the limiting amino acid into the carotid would correct the imbalance in the pattern of amino acids passing directly to the brain and allow recovery in food intake. If infusion is into the jugular vein, however, the limiting amino acid will pass to the heart and enter general circulation so that only a portion will enter the carotid artery after blood oxygenation. Of that proportion of the limiting amino acid passing to other tissues presumably much will be withdrawn to alleviate the deficit caused by feeding the imbalanced diet. Thus the effect on carotid amino acid pattern of jugular infusion will be much smaller than that of carotid infusion and a much smaller response to jugular infusion would be expected.

This interpretation has been substantiated by the identification of areas in the brain (in the prepyriform cortex and medial amygdala), the lesioning of which abolishes the decrease in food intake which results from amino acid imbalance (Leung \& Rogers, 1971 ; Rogers \& Leung, 1973). More recently several groups of workers (for review, see Booth \& Stribling, 1978) have suggested that plasma amino acid concentrations may play a key role in determining food intake because of their influence on the concentration of brain neurotransmitters. It is not yet clear whether food-intake-controlling centres in the fowl are homologous with those in the mammal, but in general the control systems appear similar.

Our results also showed that the infusion of lysine either into the carotid artery or the jugular vein caused decreased intake of a diet in which the amino acid pattern was balanced. The responses of animals to excesses of single amino acids are less well understood than those to incomplete mixtures (classical imbalance). In feeding experiments it has been shown that the amino acid in excess accumulates in the blood and that less food is eaten. In some instances, for example with an excess of lysine or leucine, a deficit of another amino acid in the plasma (arginine or isoleucine and valine respectively) is created and it might be speculated that such deficits act as signals for the food intake response by the mechanism described previously. Since not all amino acids participate in such antagonism and for those that do there is conflicting evidence from feeding experiments as to the involvement 
of decreased food intake in the over-all development of the antagonism (Harper et al. 1970; D'Mello \& Lewis, 197I; Austic \& Scott, 1975), this mechanism seems unlikely. This is substantiated by the results from lesioning experiments with rats which show that the areas of the brain mediating the response in food intake to deficient and classically imbalanced patterns of amino acids do not mediate the response to excesses of single amino acids (Rogers \& Leung, 1973).

Our experiments with lysine infusion imply that there is a direct effect of an excess of single amino acid on food intake. Although the possibility of arginine depletion causing this effect was not entirely eliminated, the rapidity of the development of the decrease in food intake and the apparent difference in the intensity of the effects caused by carotid and jugular infusions (Table 4) argue against this possibility. If depletion of arginine was essential for the food intake response the route of administration of the lysine would be irrelevant since the depletion of arginine requires blood to pass through other organs (notably the kidney). However, a direct effect of the amino acid is consistent with a greater effect on food intake when infusion is via the carotid artery and furthermore, as was noted from the present results, some effect of jugular infusion is to be expected. In the instance of large excesses of single amino acids infused via the jugular vein into birds receiving a balanced pattern of amino acids, removal of the amino acid in excess by tissues would be minimal and much would persist to affect the pattern in carotid blood. Thus the marked difference in responses to jugular infusions in the two experiments reported is explicable.

Further consideration is required to reconcile the suggestion from these infusion studies that an amino acid in excess can decrease food intake directly rather than by producing a deficit of other amino acid(s) as suggested by some feeding studies (Jones, 1964; D'Mello \& Lewis, 1971).

A studentship and support from the British Egg Marketing Board Research and Education Trust is acknowledged. We also wish to thank Mr P. Lerman, Department of Applied Biology, and the ARC Unit of Statistics at the University of Cambridge for assistance with statistical analysis.

\section{REFERENCES}

Austic, R. E. \& Scott, R. L. (1975). J. Nutr. 105, 112.

Booth, D. A. \& Stribling, D. (1978). Proc. Nutr. Soc. 37, 181.

D'Mello, J. P. F. \& Lewis, D. (1971). Br. Poult. Sci, 12, 345.

Dunnett, C. W. (1955). J. Am. Stat. Ass. 50, I096.

Harper, A. E., Benevenga, N. J. \& Wohlhueter, R. M. (1970). Physiol. Rev. 50, 428.

Jones, J. D. (I964). J. Nutr. 84, 3 I 3 .

Leung, P. M.-B. \& Rogers, Q. R. (1969). Life Sci. 8, I.

Leung, P. M.-B. \& Rogers, Q. R. (I97I). Am. J. Physiol. $221,929$.

Mellinkoff, S. M. (1957). A. Rev. Physiol. 19, 175.

Rogers, Q. R. \& Leung, P. M.-B. (1973). Fedn Proc. Fedn Am. Socs exp. Biol. 32, 1709.

Solberg, J., Buttery, P. J. \& Boorman, K. N. (1971). Br. Poult. Sci. 12, 297.

Tobin, G. (1974). Amino acid interactions in the young cockerel. PhD Thesis, University of Nottingham. 